\title{
From Thai Country Songs to German Singable Lyrics: Creative Translation in Foreign Language Teaching
}

\author{
Korakoch Attaviriyanupap \\ Department of German, Faculty of Arts, Silpakorn University, Thailand
}

Copyright $(02016$ by authors, all rights reserved. Authors agree that this article remains permanently open access under the terms of the Creative Commons Attribution License 4.0 International License.

\begin{abstract}
Translating song lyrics between two typologically and phonologically different languages requires not only language competency in both source and target languages, but also creativity and problem solving skills, especially when the translated version has to be singable along with the original melody. This paper presents results of an analysis of problems found in the process of translating Thai country songs into German and how this kind of "creative" translation can be made useful in the teaching process of German as a foreign language. Translation problems found can be divided into 7 categories: a deficit in German language skills; a deficit in Thai language skills; differences between the two language systems; the problems of conveying the entire message in the original text; differences between the two cultures; the problems of translating repetitions, and the problems of selecting German words and linguistic structures which are appropriate for singing. These findings can contribute to the teaching of translation of this music genre into German and can be applied to other song genres of other source languages. Translated song lyrics can also be used as materials in various classes of German as a foreign language.
\end{abstract}

Keywords Creative Translation, Thai Country Songs, German, Foreign Language Teaching

\section{Introduction}

Song lyrics belong to an important medium to reflect human languages and cultures. Lukthung, short for phleng lukthung (lit. "song of a child of the fields"), often referred to as Thai country music, is an acculturated song genre of Thailand which draws on modern and traditional cultural forms, and appeals to both urban and rural populations [1]. Since this music genre typically reflects the hardship of everyday life among the rural poor, it is appropriate to be chosen for song translation in terms of intercultural aspects. To translate these kinds of lyrics, a functional approach must be applied and creativity is needed. In the process of translating song lyrics, one is not only confronted with technical, linguistic and cultural problems, but also several factors interacting at the same time, especially when singability along with the original melody has to be considered.

This paper focuses on the analysis of problems found in the students' processes of translating these songs and the application of problem solving strategies as well as possibilities of integrating this kind of translation in the process of teaching German as a foreign language in a Thai context. The main approach is the concept of "creative translation" introduced by Paul Kußmaul[2],[3]. In the translation process, creativity must be applied in order to make the translation achieve the same objectives as the original, especially when the source and the target languages are strongly different from each other.

\section{Objectives, Methods and Corpus}

\subsection{Objectives and Methodology}

The objectives of this study on problems in translating Thai country songs into German were to analyze problems and errors occurring in the translation process and to suggest guidelines to solve these problems. The research was conducted in 7 steps:

- Collection of Thai Lukthung songs which had already been written in or translated into German before by my students and me.

- Selection of 16 original Lukthung songs to be translated, 4 songs for group work and 12 for individual translation.

- Giving a short lecture on "the translation of a Lukthung song" in a session of the course "Translation II". The content of my lecture reflected experience and problem strategies in Lukthung song translation in the previous academic year. Four songs were used in class for practice purposes, each being translated by two groups of students. After their presentation of the translated versions, they had to 
finish the translation of the whole song and hand in the translation within one week.

- The other 12 songs were distributed by lot. Each student was assigned to translate 2 songs and hand in the translation twice. At first they handed in a draft of their translation. They did not have to finish the whole song, but they also wrote down problems they had encountered. After my rough feedback on their first drafts, they continued the translation and then handed in the complete translated texts. A period of about 6 weeks was given in total for the whole translation process.

- The translation was grammatically corrected by a native speaker and me and some problems of translation were discussed in the last session of the course.

- All the translated texts were analyzed for the purpose of this research.

\subsection{Analyzed Corpus}

The data was collected from German texts translated by Silpakorn University's fourth year German major students in the course "Translation II" in the winter semester of the academic year 2013. 35 students enrolled on this course. For the analysis of translation problems, there were either two, five or six translated versions to be compared. The corpus analyzed for this research consisted of 78 texts listed in Table 1 .

Table 1. Thai country songs selected as the original and the number of translated texts analyzed

\begin{tabular}{|c|c|c|c|c|c|}
\hline & \multirow{2}{*}{ Song title } & \multirow{2}{*}{ Composer } & \multirow{2}{*}{ Singer } & \multicolumn{2}{|c|}{$\begin{array}{c}\text { Number of translated } \\
\text { versions }\end{array}$} \\
\hline & & & & group & individual \\
\hline 1 & fǒn du:an hòk ('Rain of May') & Phaiboon Butkhan & Rungphet Laemsing & 2 & \\
\hline 2 & $\begin{array}{c}\text { hǔ:achaj phǒm wăng ('My heart is } \\
\text { unoccupied') }\end{array}$ & $\begin{array}{c}\text { Suraphon } \\
\text { Sombatcharoen }\end{array}$ & $\begin{array}{c}\text { Suraphon } \\
\text { Sombatcharoen }\end{array}$ & 2 & \\
\hline 3 & khithǔng cang lr:j ('Miss you so much') & Nopphorn Muangsuphan & $\begin{array}{c}\text { Nopphorn } \\
\text { Muangsuphan }\end{array}$ & 2 & \\
\hline 4 & $\begin{array}{c}\text { rô:nghâ:j kàp dui:an ('Crying with the } \\
\text { moon') }\end{array}$ & Khamphee Saengthong & Khamphee Saengthong & 2 & \\
\hline 5 & $\begin{array}{c}\text { krà:p thá:w jâ: mo: ('Prostrating before Ya } \\
\text { Mo's feet') }\end{array}$ & Loet Sirichok & Sunaree Ratchasima & & 6 \\
\hline 6 & $\begin{array}{l}\text { khondang lui:m lang khwa:j ('Famous man } \\
\text { forgets the buffalo's back') }\end{array}$ & Chalong Phusawang & $\begin{array}{c}\text { Phumphuang } \\
\text { Duangchan }\end{array}$ & & 6 \\
\hline 7 & $\begin{array}{c}\text { campa: lu:m tôn ('The flower Champa } \\
\text { forgets its tree') }\end{array}$ & Chonlatee Thanthong & Sayan Sanya & & 6 \\
\hline 8 & chănthana: thî:rák ('My dear Chanthana') & Suchart Thianthong & Rakchart Sirichai & & 5 \\
\hline 9 & dùa:n phitsawă:t ('Express train of love') & $\begin{array}{c}\text { Suraphon } \\
\text { Sombatcharoen }\end{array}$ & Phongsri Woranuch & & 6 \\
\hline 10 & ja:caj khon con ('Sweetheart of a poor man') & Sala Khunawut & Mike Phiromphorn & & 6 \\
\hline 11 & $\begin{array}{c}\text { rú: wâ: khăw lj:k('I know that he has cheated } \\
\text { me') }\end{array}$ & Karn Karunwong & Sirinthra Niyakorn & & 6 \\
\hline 12 & $\begin{array}{c}\text { rák cing hâj tingnang ('If you love me, please } \\
\text { ting nang') }\end{array}$ & Jenpob Jobkrabuanwan & Rung Suriya & & 6 \\
\hline 13 & $\begin{array}{c}\text { lông rul:a hă: rák ('Floating on the boat } \\
\text { searching for love') }\end{array}$ & Chonlatee Thanthong & Suriyan Songsaeng & & 5 \\
\hline 14 & să:m hò: să:m châ: ('Three times yodel') & Lop Burirat & Kathaleeya Marasri & & 6 \\
\hline 15 & $\begin{array}{l}\text { nùmna: rJ: na:ng ('A swain waits for his } \\
\text { girl') }\end{array}$ & Sanit Manorat & Waiphot Phetsuphan & & 6 \\
\hline 16 & jà:k dang ('Desire to be famous') & Saman Muangrat & Kangwanphai Lukphet & & 6 \\
\hline
\end{tabular}


Table 2. Translation of repetition in the song rák cing hâj ting nang ('If you love me, please ting nang')

\begin{tabular}{|c|c|}
\hline Original text & Suggested Translation \\
\hline 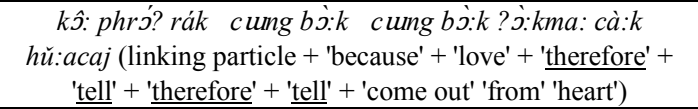 & 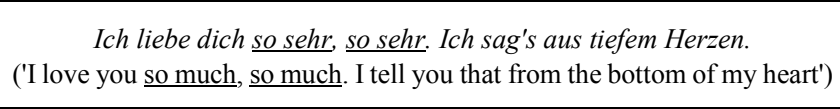 \\
\hline 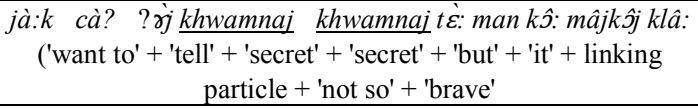 & $\begin{array}{l}\text {..., will ich dir was sagen, was sagen, aber ich wag' es doch nie ('I want to } \\
\text { tell you something, tell you something, but I never dare to say it') }\end{array}$ \\
\hline 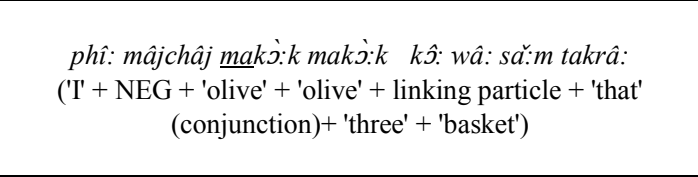 & $\begin{array}{l}\text { Ich bin nicht aalglatt, nicht aalglatt. Ich belüge dich nie. } \\
\text { ('I am not slippery as an eel, slippery as an eel. I never lie to you') } \\
\text { Note: The word makj:k ('olive') is not really meant 'olive' in this context } \\
\text { but it is a part of a Thai phraseology makj:k să:m takrâ: pa: mâj thûu:k } \\
\text { which is used to describe a person who is slippery as an eel. }\end{array}$ \\
\hline 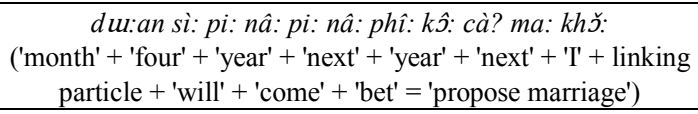 & $\begin{array}{l}\text { Im nächsten März, im März, will ich dich heiraten } \\
\text { ('in March next year, in March, I will marry you') }\end{array}$ \\
\hline $\begin{array}{c}\text { wan nán la nכ̌: la nว̌: phî: cà? khว̌: tingnang } \\
\text { ('day' + 'that' + particle + particle + 'I' + 'will' + 'ask for' } \\
\text { 'ting-nang') }\end{array}$ & $\begin{array}{l}\text { Wenn der Tag kommt, er kommt, will ich dann Ting Nang } \\
\text { (When that day comes, when it comes, I will ting-nang then') } \\
\text { Note: The word ting nang does not have a meaning in Thai either. It is an } \\
\text { artificial word the composer invented, a kind of onomatopoeia of Thai } \\
\text { traditional music instruments. }\end{array}$ \\
\hline
\end{tabular}

Table 3. Comparison of two different translated versions

\begin{tabular}{|c|c|c|}
\hline $\begin{array}{c}\text { Content and number of syllables } \\
\text { in the original version }\end{array}$ & Version 1 and the number of syllables & Version 2 and the number of syllables \\
\hline Perhaps someone (3) & Kann es sein, (3) & Vielleicht hast du jemanden,(7) \\
der um deine Gunst wirbt. (6) \\
is taking very good care of you. (6) & dass du jemanden hast, (6) & Du vergisst also dein'n Mann.(8) \\
Thus, you forget the man who loves you (7) & der viel besser ist als ich? (7) & Weißt du, dass ich einsam bin? (7) \\
And you leave me waiting lonesome (6) & D'rum lässt du mich allein.(6) & Ich schau' den Mond an, (5) \\
When I look at the moon, (4) & Ich bin traurig,(4) & den ich gefürchtet hatte. (7) \\
it seems to make me frightened (6) & immer wenn ich den Mond seh' (7) & In der Nacht. Oh, der Mond, (6) \\
Especially this night, the moon is bright(5) & In dieser hellen Nacht (6) & ich weine mit dir. (5) \\
I come to cry with the moon (6) & weine ich mit dem Mond.(6) & \\
\hline
\end{tabular}

\section{Problems in Translating Thai Country Songs into German}

The translation problems found in the analysis can be divided into 7 categories: 1) a deficit in German language skills, 2) a deficit in Thai language skills, 3) the problems of differences between the two language systems, 4) the problems of differences between the two cultures, 5) the problems of conveying the entire message in the original text, 6) the problems of translating repetitions, and 7) the problems of selecting German words and linguistic structures which are appropriate for singing. While the first four aspects can be regarded as general translation problems, the last three translation problems are especially important for the translation of Thai Lukthung songs.

\subsection{Deficit in German Language Skills}

This problem is quite a general one for translation classes. The students who translated the Lukthung song lyrics in this research were only at the B2 level according to the CEFR (Common European Framework of Reference for Languages), thus their German was far from a native-like level and they made a lot of errors in German which included errors in the vocabulary (e.g. the use of warnen 'to warn' instead of erinnern 'remind' because both words can refer to the same verb in Thai), expressions (e.g. Wort zerbrechen 'word' + 'break' instead of Wort brechen 'word' + 'break' to refer to the meaning of 'to break one's word') and grammatical errors (e.g. wrong inflected forms, use of wrong articles, word order etc.).

\subsection{Deficit in Thai Language Skills}

Even though Lukthung song lyrics are principally characterized as a text genre, in which simple and easily understandable language is used [4], the deficit in one's own mother tongue can always happen and is not limited to the translation of Lukthung songs. O'Charoen[5] also mentioned this translation problem in her research on translation problems of German poetry into Thai. In this study, it was remarkable that sometimes the students did not understand Thai words correctly, for example the terms jângkhâw du:an hok means 'entering the sixth month', but some of them translated this temporal description as bald ist es Juni ('Soon, it will be June'). The verb element thing ('leave') in combination with cotma:j ('letter') in the sentence nâng khǐ:an còtmǎ:j l'́: w rî:p thíng paj ro:nga:n ths:phâ: ('sit' + 'write' + 'letter' + 'then' + 'hurry' + 'drop' + 'go' + 'factory' 'weaving') in the song chănthana: thî:rák ('My dear Chanthana') means 'to post a letter', but one student understood that the man in the song "sat writing a letter, and then he left it there and hurried to the textile factory" which was totally wrong. 


\subsection{Differences between the Two Language Systems}

While German is an inflecting language with complex morphology, Thai is an isolating one which functions mostly at a syntactical level. The difference in the sentence structure which leads to one of the most frequent translation problems is the fact that subjectless sentences are quite common in Thai, but to translate sentences into German, the subject must always be identified. The beginning verse of the song chănthana: thî:rák ('My dear Chanthana') can illustrate this problem very well:

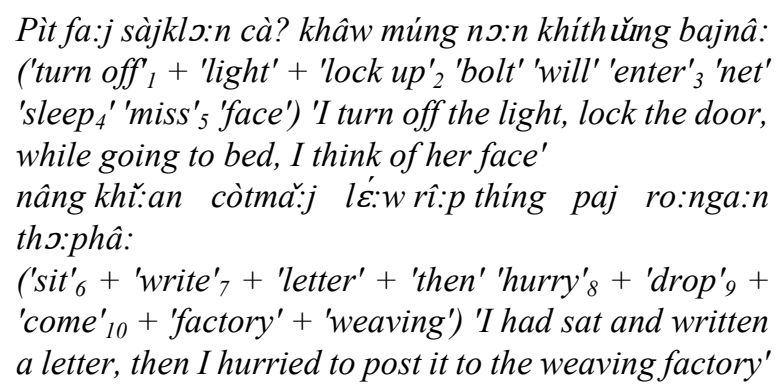

Most of the students found it very difficult to translate the above sentence because there are ten verbs in total without a single subject. As a result, some of them just left the subject out, but this is not a good strategy to solve the problem, especially when they are not aware of grammatical errors. Subjectless sentences are mostly imperatives in German, which are not the same as the sentences above.

Another difference between the two languages identified as a problem in the translation process is the use of personal pronouns and kinship terms, especially when they are used for non-relatives, such as the term "Ya Mo" (literally meaning 'father's mother' + the name of a woman) for a Thai heroine in the song krà:p thá:w jâ: mo: ('Prostrating before Ya Mo's feet'), which has different results in the use of Thai words and their meaning from the direct translation. Translating this address and kinship term as Großmutter ('grandmother') was not correct, because German culture does not use this term with their historical heroines.

The differences in the sound system of German and Thai also cause difficulties in translation. It is not easy to select words of the same meaning in both languages with roughly the same number of syllables. Furthermore, one may find neither similar stress patterns nor syllable structures. However, syllable structure and stress patterns are of the highest importance in translating song lyrics which must be singable. Thus, not only must the strategy of using synonyms in word choice always be applied, but translators also always have to paraphrase sentences to make the syllable structure suit the melody in terms of combination of consonants and vowels and its length. If the sentence ends with a long note and is a vibrato, in the translated version, an open syllable with a long vowel should be used. For example, the final syllable -füllt with its structure of CVCC with a short vowel does not fit here at all. One has to choose the translated version Alle Wünsche werden wahr ('All the wishes become true') with the final word as a long, open syllable (CV) instead of Alle Wünsche werden erfüllt ('All the wishes are fulfilled').

\subsection{Differences between the Two Cultures}

Like translating any other genres of literary and song texts, cultural codes and customs also had to be taken into consideration. In the corpus, some interesting aspects were found such as the naming of the months, flowers, trees, traditional festivities, attitudes, beliefs within a social context, as well as terms of endearment used for addressing beloved ones.

For example, there are two ways of naming the twelve months of each year. If the international version, i.e. January to December, is used, then there is no problem in translation. However, in Lukthung songs, another, more traditional, way, is more often used. The months are named in the form of ordinal numbers; however, unlike the international way where January is counted as the first month, the naming of months is according to the lunar system. For example, the first month, which mostly refers to December, is called du:an ? $\hat{a}: j$ in Thai, and then comes January as the second month. Some students mixed up these two different systems causing translation errors. To translate Thai Lukthung songs into German, Thai culture should be kept as faithful to the original and real context as possible, as in the case of the months.

Some words are more functional than semantically relevant and thus should be adapted to be understandable in the target language, for example terms of endearment. Regarding these words, which also appear often in Lukthung lyrics, the students mostly tried not to translate them word for word. Instead, they used only a limited number of words which they already knew such as Schatz or Süße, which are equivalent to the English honey or sweetheart. In fact, it is quite challenging to try to match Thai terms of endearment with German ones, for example the Thai form $p h \hat{\jmath}: d s: k$ sàdaw ('father' + 'flower of a neem tree') should be translated

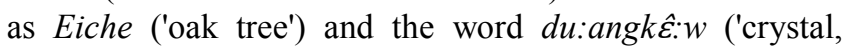
sweetheart') as Augenstern ('star of the eyes'), since both are pet names found in German and share some similarities with the Thai original version. In the first case, terms of endearment representing males which mean 'flower' are quite unusual in German, so in this case a term for a tree is chosen instead. The term Augenstern is suitable for the

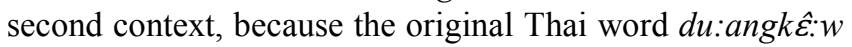
in the song dùa:n phitsawa:t ('Express train of love') is used twice, the first time to refer to the eyes of the protagonist filled with tears, and the second time to refer to her beloved man. The term Augenstern was chosen in my suggested translation version, because it also contains the word Augen ('eye'). Nowadays, pet names in German are much easier to find via the internet. However, before choosing any forms of this kind of culture-specific words for translation, consultation with a native-speaker of German is essential.

\subsection{Restrictions of Completeness with Regard to Contents}


To provide a translation with total content equivalence to the original might not be problematic if the translation is free from the restrictions of singability like the German Lukthung songs in the framework of the present study. The translation is thus a paraphrase with both addition and omission in order to fit the music. In fact, the moods of the song showing the main character in the songs are love, sorrow, disappointment, or joy. This aspect is of great importance and should not be ignored, while the contents may not have to be translated in every detail to keep the translation singable. The ability to decide which contents can or cannot be omitted, as well as which kind of information has to be added to help to convey the culture-specific message, is much more important.

An example of this problem found in the analyzed corpus is in the song khithuǔng cang lช:j ('Miss you so much') when

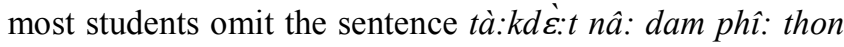
tham paj ('dry in the sun' + 'face' + 'black' + 'I' + 'endure' + 'do' + 'come' = 'I am burned by the sun, my face becomes dark, but I still endure it and do it further'). The cause of the omission was because they were not able to express this sentence within only eight syllables as fixed by the original lyrics. However, this is an important description of the hard life of this poor man and should not be neglected. One possible way to keep the message in the translation was the combination of using a grammatical structure which is as short as possible and making use of the vibrato of this song by adding some more syllables in the translated version. My suggestion is sonnenverbrant, dennoch tu' ich das ('sunburnt' + 'nevertheless' + 'do' + 'I' + 'that' = 'Though being sunburnt, I still do that'.

Translating Thai Lukthung songs into German is definitely not a literal translation which completely conveys the same content as in the original, but it is more about sense translation or paraphrasing. However, one can only omit a message which does not belong to the central idea or the main scene of the song lyrics in order not to ruin the mood of the song.

\subsection{Translating Repetitions}

Repetition can be regarded as a style, which is also normally an important factor in literary and song translation, since one of the purposes of the translation is to reproduce the stylistic features of the original songs in term of the combination of music and lyrics. This problem should be reduced by trying to move the repetition to the right position to match the repeated notes in the melody. In the corpus, there are three types of repetition: repetition of whole paragraphs or sentences as found in refrains or at the beginning of a new stanza, repetition of words within a sentence, and repetition of syllables in the form of reduplication. The first category is mostly found as repetition in the analyzed corpus and does not seem to be problematical for the students. They just copied the translation of these repeated sentences where applicable. On the contrary, reduplication in Thai is not only a literary device, but it is a morphological mechanism used to express different meanings such as pluralization, intensification or attenuation, so the reduplicatives in the original Thai song lyrics are not translated into reduplicatives in German which are quite rare [6], but into their functional equivalents which have various forms [7]).

Remarkably, in the corpus of this study, repetition of words or syntagmas occurs in five songs and especially in the song rák cing hâj ting nang ('If you love me, please ting nang'). Most of the students tried to reflect this strategy in their translation, however sometimes with problems, for example, a student translated the sentence $k \hat{j}$ : phró? rák cung bj:k cung bj:k ?j:kma: cà:k hŭ:acaj (linking particle + 'because' + 'love' + 'therefore' + 'tell' + 'therefore' + 'tell' + 'come out' 'from' 'heart') as Weil ich dich liebe. Die Liebe aus meinem Herzen ('because' + 'I' + 'love' + 'you' + 'the' + 'love' + 'from' + 'my' + 'heart'). However, in this sentence, the words repeated are not the same because they belong to different word classes. Table 2 shows the suggested translation of repetitions in this song.

\subsection{Singability}

Singability plays the most important role in the translation of Thai country songs into German. The following comparison of two translated versions of the same stanza of the song rô:nghâ:j kàp dul:an ('Crying with the moon') in Table 3 shows the differences between them in the aspect of singability, especially in the matter of the number of syllables which should be taken into account at the first step.

Since the melody is pre-existing and cannot be changed, the selection of words and linguistic structures to fit it is almost like the construction of a crossword. The position of pause and transition in the translated lyrics should also be coherent where singers can take a breath or produce a vibrato in the case of very long notes. To create a singable German translation of Thai Lukthung songs, the translators have to consider all the aspects of sound systems in German.

Although the transfer of the meaning in both translated versions is of about the same quality, we may conclude that the first translated version in the middle column is obviously a better version in terms of singability, because it has almost the same number of syllables in each line compared to the original.

In cases where the Thai words should be kept (e.g. person or place names), it is also important to try to put them in their original position. If this is not achieved, and especially when the vowel in the last syllable is not a long one as in the original Thai song, it will not sound right when sung with the melody and will not convey an equivalent context emotionally and aesthetically. We can see the differences in the following three translations of a verse from the song chànthana: thî:rák ('My dear Chanthana') which ends with the word Chanthana, a Thai woman's name:

rák sǎw ro:nga:n sǎw ro:nga:n chû: chǎnthana: ('love' + 'young woman' + 'factory' + 'young woman' + 
'factory' + 'name' = 'I love a woman factory worker, the woman factory worker named Chanthana' Ich liebe Chanthana, die Weberinmädchen ist [8.2] ('I' + 'love' + Chanthana + the + 'woman working in the weaving factory') 'I love Chanthana who is a woman working in the weaving factory'

The above translation ends with a short syllable with a consonant cluster. This means that it does not fit the music which ends with a long note and open syllable in the word Chanthana. Moreover, the repetition in the original text was not transferred. Therefore, it is suggested that the word Weberin is repeated twice and the Thai word Chanthana is placed exactly at the same position as in the original.

Ich lieb' 'ne Weberin. Die Weberin heißt Chanthana ('I' + 'love' + 'a' + 'female weaver' + 'the' + 'female weaver' + name' + Chanthana) 'I love a female weaver. The female weaver's name is Chanthana'.

\section{Singable Translated Song Lyrics in GFL Courses}

The process of this kind of creative translation and the singable translated song lyrics can be made useful in the teaching process of German as a foreign language. Here are some course types in which this kind of translation can be applied or the finished translated texts can be used.

\subsection{Singable Translated Song Lyrics in a German Translation Course}

The problems found must be avoided through training in the translation course. Moreover, these findings can contribute to the teaching of translation of this music genre into German and can be applied to other song genres of other source languages or even to other source or target languages. In German translation courses, the strategies suggested to each problem can be taught and practiced systematically and a focus can be made explicitly to this kind of translation if an extra course on song translation can be offered. Otherwise, this topic can be integrated into a literary translation course.

It is especially important to discuss more broadly the use of different words (synonyms) or variation of linguistic structures of the German language (e. g. phrases vs. clauses) to search for the most appropriate version of the translation where the German lyrics can be sung to the original Thai melody. Several important strategies have to be suggested, and practiced, such as using different kinds of dictionaries (e.g. dictionary of synonyms) and internet searching engines (e.g. regarding endearment terms) as well as consulting with native speakers.

\subsection{Singable Translated Song Lyrics in a Phonetics Course}

Translated Lukthung song lyrics in German can also be used in a Phonetic Course in two aspects: to train learners' pronunciation and to compare the sound systems of Thai and German. The most challenging part to use singable translated song lyrics for German pronunciation training is that the Thai original music always makes the translated songs sound strange, even though the text is written in German. Thus, the learners will have to overemphasize their articulation to make the songs sound more German or be able to be understood by native speakers of German. Since German Lukthung songs were performed by our students on various occasions, singers always confirmed that through singing, they have all greatly improved their pronunciation in German [8]. Therefore, this kind of songs should also be made useful for this purpose in classroom context. Since a phonetics course at university level mostly also include the theoretical parts, the singable translated song lyrics can also be used as materials for comparing the German and the Thai sound systems. Through analyzing the original Thai texts with the German translation, learners can also get more knowledge on their differences and the phonetically relevant strategies used to translate such song lyrics.

\subsection{Singable Translated Song Lyrics in Grammar Teaching}

Translated Lukthung songs can also be an integrated part of the teaching of German grammar. This kind of texts can be brought into class and taught in terms of vocabulary and syntax. The atmosphere will be enjoyable and the students will able to remember several expressions in German through singing along.

The usage of songs in the foreign language classroom is certainly not a new technique and the fact that the integration of target language lyrics and melodies into classroom grammatical lessons can enhance the student's ability to recall specific points of grammar can be common [9]. Learners will even pay much more attention to the songs when they are translated by themselves or people they know such as their classmates or senior students or graduates. In my experience, this strategy of song selection has worked very well and should be used as one of the criteria in the integration of music into a foreign language classroom.

Moreover, in the process of German grammar teaching, there is a task which has always been important, the so called "Umformung" or the "structural transformation". This means learners are always trained to transform German expressions into other constructions with the same meaning, and this competency is really useful and even necessary in the process of translating Thai Lukthung lyrics into German.

\section{Conclusions}

Translating song lyrics means we are dealing with vocal music which is a combination of lyrics and melody. To provide a "singable" translation, not only can we not ignore the content and cultural equivalence, but also equivalence in 
terms of rhythms, note-values, syllable structure, stress patterns and phrasing cannot be ignored. Lukthung's expressive qualities are contained in vocal quavers, especially when expressed in the frequent use of elongated or shortened vibratos, while, on the other hand, there are also many vivid and lively Lukthung songs allowing translators to play with different word structures of another sound system. This creates challenges for a translator when translating song lyrics into another language.

To provide a reproduction of the original in the target language which is as close as possible to the original, a functional approach, especially the concept of "creative translation" is recommended. The main idea of creative translation is to provide a translation which reflects two important factors: originality and adequacy [4]. Song translation cannot be interpreted as mathematical meaning of identity, but only on the basis of the highest degrees of closeness to functional identity. A good translation of Thai Lukthung songs into German should reflect creativity in terms of originality by not just blindly counting the syllables, but also trying to put the right words to the right music by making use of knowledge of German sound systems and grammar. Additions, paraphrases, omissions and reorganizations are all techniques which have to be used. Translating Thai Lukthung songs into German is especially of value to those who wish to refine their students' sensibility to alternate ways of expressing meaning with the emphasis on different aspects at the same time: accuracy, clarity and flexibility. It can be integrated in a special way into a translation course, which can only be possible in the Thai context and thus has both practical and theoretical implications.

The increase of competency in the German language can be combined with reflections on one's own culture. Lukthung songs are thus a good choice for this intercultural concept and worthy of further analysis, both in terms of research and foreign language teaching, especially because the "Lukthung" language shows a kind of simplicity and straightforwardness. These characteristics should support the process of foreign language learning. The findings of this research should be used to develop appropriate translation methods and contribute to the teaching of the translation of this music genre into German. The knowledge gained can also be applied to other song genres and the translated texts can be used as teaching materials in various GFL classes for
Thai learners.

\section{Acknowledgements}

The content of this paper is mostly based on the results of the research project "Problems in Translating Thai Country Songs into German" which was supported by the Faculty of Arts, Silpakorn University.

\section{REFERENCES}

[1] J. .Mitchell, Khon Ban diao kan or 'we're from the same village: star/fan interaction in Thai Lukthung, Perfect Beat 12.1, 68-89, 2011.

[2] P. Kußmaul, Kreatives Übersetzen, Stauffenburg, Tübingen, 2000.

[3] P. Kußmaul, Verstehen und Übersetzen. Ein Lehr- und Arbeitsbuch, Narr, Tübingen, 2010.

[4] C. Damronglert, Thai Country Song Literature: Ritual, Tradition, Value and Way of Life of Thai Country People Reflected in Thai Country Songs from After World War II to Present. Institute of Thai Studies, Thammasat University, Bangkok, 1990.

[5] T. O' Charoen, Translation of German Lyrics into Thai. A Case-Study of Problems in Translating German Lyrics of Graduate Students of the Faculty of Arts, Chulalongkorn University, Journal of Faculty of Arts 31, 1: 1-33, 2002.

[6] M. Schümann, Wortbildung, In E. Hentschel, P.M. Vogel (eds.), Deutsche Morphologie, De Gruyter, Berlin/New York, 390-395, 2010.

[7] K. Attaviriyanupap, Reduplicatives in Thai and Their Equivalents in German, NIDA Journal of Language and Communication 20, 26, 110-133, 2015.

[8] K. Attaviriyanupap, The Integration of Lukthung Songs into the German Language Teaching and Learning Process of Thai Students, MANUSYA Journal of Humanities 17,2, $17-28,2014$

[9] D.J. Kramer. A Blueprint for Teaching Foreign Languages and Cultures through Music in the Classroom and on the Web. ADFL Bulletin 33, 29-35, 2001. 